\title{
BRAZILIAN NATIVE SPECIES AS POTENTIAL NEW SOURCES OF NATURAL ANTIOXIDANT AND ANTIMICROBIAL AGENTS
}

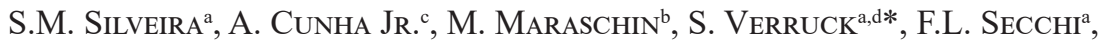 \\ G. Scheuerman ${ }^{c}$, E.S. Prudencio ${ }^{d}$, N. Fronza ${ }^{a}$, and C.R.W. Vieira ${ }^{d}$ \\ ${ }^{a}$ Center of Food Science and Technology, Federal Institute of Education, Science and Technology, SC 283, km 08, \\ P.O.Box 58, 89700-000, Concórdia, SC. Brazil \\ ${ }^{b}$ Plant Morphogenesis and Biochemistry Laboratory, Admar Gonzaga 1346, Itacorubi, 88034-001, Federal \\ University of Santa Catarina, Florianópolis, SC. Brazil \\ ${ }^{c}$ Embrapa Swine and Poultry, BR 153, km 110, P.O.Box 21, 89700-000, Concórdia, SC. Brazil \\ ${ }^{\mathrm{d}}$ Department of Food Science and Technology, Federal University of Santa Catarina, Admar Gonzaga 1346, \\ Itacorubi, 88034-001, Florianópolis, SC. Brazil
}

(Received: 25 April 2019; accepted: 27 June 2019)

\begin{abstract}
The antioxidant and antimicrobial activities of extracts of 12 plant species growing in Brazil were determined. Antimicrobial activity against 12 food-related bacterial species was studied using the disc-diffusion, MIC, and MBC methods. Campomanesia eugenioides extract was the most active against the tested Gram-positive bacteria, whereas Parapiptadenia rigida bark extract presented the highest activity against the evaluated Gram-negative bacteria (MIC and MBC of 0.075 and $0.62 \mathrm{mg} \mathrm{ml}^{-1}$, respectively, against Pseudomonas aeruginosa). Those two extracts also presented high phenolic content and high DPPH and ABTS radical scavenging ability. C. eugenioides extract presented high $\mathrm{Fe}^{2+}$ chelating capacity. The results of the present study demonstrate that, among the evaluated extracts, P. rigida bark and C. eugenioides, both Brazilian native species, presented the highest potential of application as natural antimicrobial and antioxidant agents.
\end{abstract}

Keywords: bioactive compounds, medicinal plants, polyphenols, plant extracts, natural additives

Brazil has the greatest biodiversity of the planet. This abundant variety of life corresponds to more than $60 \%$ of the country covered with vegetation. This biodiversity is still little known, as studies are still modest, so as new studies and research are unfolding, the bioactive potential of many other known or yet unknown species will undoubtedly be revealed (OLIVEIRA et al., 2017). Species of Campomanesia, Parapitadenia, Eugenia, and Psidium among others used in this study are native in the Atlantic Rainforest biome, one of the six important biomes present in Brazil (ZAPPI \& BFG, 2015). Species like these can be carriers of substances or molecules with great bioactive potential. Studying these plants may discover new cures for old and emerging diseases or benefiting food preservation. Toxicity issues and the current consumers' preference for natural and healthier products have led to an increasing search for natural additives capable of preventing undesirable changes in foods (EBRAHIMABADI et al., 2010).

Despite the development of several food preservation methods, food-borne diseases are still a major public health concern worldwide and the prevalence of antibiotic-resistant pathogens should also be taken into account (CELIKTAS et al., 2007). The benefits of the application of natural products and molecules range from the food preservation to the inclusion of supplemental nutritional factors and health-benefiting properties. Additionally,

\footnotetext{
* To whom correspondence should be addressed.

Phone: +55 49 998089107; email: silvani.verruck@gmail.com
} 
their market advantages are also evident due to the strong current demand for natural, nontoxic, and environmentally safe food products. Therefore, the assessment of plant materials with both antioxidant and antimicrobial activities is one of the main goals of the research on food additives (EBRAHIMABADI et al., 2010).

The main objectives of the present study were: (1) to determine the contents of total phenolic and flavonoid compounds in extracts of 12 Brazilian native plant species; (2) to evaluate their antioxidant activity; and (3) to evaluate their antimicrobial activity against 12 food-related bacterial species, aiming at identifying the most promising species to be used as natural food preservers and antioxidants.

\section{Materials and methods}

\subsection{Plant material and extract preparation}

Voucher numbers, common and scientific names, and parts used for extract preparation are listed in Table 1. The plant material was dried in a forced-ventilation oven at $40{ }^{\circ} \mathrm{C}$ for $48 \mathrm{~h}$. The material was then ground and extracted by exhaustive maceration in an ethanol:water solution at 80:20 (v/v). The solvent was removed at $50{ }^{\circ} \mathrm{C}$ under reduced pressure in order to obtain hydro-alcoholic crude extract. The extracts were stored under refrigeration $\left(0-4{ }^{\circ} \mathrm{C}\right)$ in the dark.

Table 1. Scientific name, voucher number, and part of the plant used for hydro alcoholic extraction

\begin{tabular}{lcc}
\hline Scientific name & Part used & Voucher number \\
\hline Arctium minus (Hill) Bernh & $\mathrm{L}$ & HVAT 2609 \\
Campomanesia eugenioides & $\mathrm{L}$ & HVAT 2612 \\
Cynnamomum zeylanicum Blume & $\mathrm{B}$ & HDCF 5538 \\
Diospyros kaki & $\mathrm{L}$ & HVAT 2597 \\
Eugenia uniflora L. & $\mathrm{L}$ & HDCF 5534 \\
Parapiptadenia rigida & $\mathrm{L} / \mathrm{B}$ & HVAT 2608 \\
Persea Americana Mill. & $\mathrm{L}$ & HVAT 2606 \\
Plinia edulis (Vell.) Sobral & $\mathrm{L}$ & HDCF 5579 \\
Psidium cattleyanum Sabine & $\mathrm{L}$ & HDCF 5530 \\
Psidium guajava L. & $\mathrm{L}$ & HDCF 5533 \\
Schinus terebinthifolius & $\mathrm{L}$ & HVAT 2607 \\
Syzygium cumini (L.) Skeels & $\mathrm{L}$ & HDCF 5525 \\
\hline
\end{tabular}

L: leaf; B: bark; HVAT: Herbarium of the Natural Sciences Museum of the Department of Botany and Paleobotany, Univates (RS, Brazil); HDCF: Forest Herbarium of the Dendrology Laboratory of the Forest Sciences Department (UFSM, RS, Brazil).

\subsection{Determination of total phenolic content, total flavonoid content, and antioxidant activities}

The content of total phenolic compounds in the plant extracts was determined according to SinGLETON and co-workers (1999). Total flavonoid content in the plant extracts was determined according to DEwANTO and co-workers (2002). The antioxidant activity was evaluated by 
ability of scavenging DPPH and ABTS radical according to BRAND-WILLIAMS and co-workers (1995) and RE and co-workers (1999), respectively. The assay to determine the extract chelating ability with $\mathrm{Fe}^{2+}$ was carried out according to the description of CARTER (1971) with modifications of SILVEIRA and co-workers (2014). The analyses were carried out in triplicate and the values are presented as mean \pm standard deviation (Table 2).

\subsection{Antimicrobial activity}

The plant extracts were tested against 12 bacterial strains (Table 3 ). All strains were stored at $-20{ }^{\circ} \mathrm{C}$ in the appropriate medium containing $10 \%$ glycerol and sub-cultured every two weeks on tryptic soy agar (TSA) slants maintained at $4{ }^{\circ} \mathrm{C}$. The detection of inhibitory effect of the extracts on the tested bacteria was carried out by adapted agar disc-diffusion method (CLSI, 2018a) with modifications of SILVEIRA and co-workers (2014). The diameter of inhibition zones was measured in millimetres. Tests were performed in quadruplicate and results are presented as mean \pm standard deviation. The most active extracts, as detected in the disc-diffusion test, were evaluated for their minimum inhibitory concentration (MIC) using the microdilution broth method (CLSI, 2018b) with modifications of SILVEIRA and coworkers (2014). The minimal bactericidal concentration (MBC) was determined from the microdilution plates used in the MIC assay. Aliquots $(10 \mu \mathrm{l})$ of each well without visible growth were transferred to TSA plates, incubated at $36{ }^{\circ} \mathrm{C}$ for $24 \mathrm{~h}$, and colony growth was verified. Tests were performed in triplicate, and the results were expressed in $\mathrm{mg} \mathrm{ml}^{-1}$.

\subsection{Statistical analysis}

Spearman's correlation coefficient was calculated $(\mathrm{P}<0.05)$ between all parameters evaluated, using the CORR procedure of SAS statistical package (SAS, 2003). To determine significant differences $(\mathrm{P}<0.05)$ between the results, one-way analysis of variance (ANOVA) and Tukey's test was used (SAS, 2003).

\section{Results and discussion}

Table 2 presents the content of total phenolic, total flavonoid compounds and the results of the antioxidant activity of hydroalcoholic extracts. Higher levels $(\mathrm{P}<0.05)$ of total phenolic compounds (TPC) were observed for $C$. zeylanicum, $P$. edulis, and $P$. rigida (bark) $(>250 \mathrm{mg}$ $\mathrm{GAE} / \mathrm{g})$. A TPC of $1.03 \mathrm{mg} \mathrm{GAE} / \mathrm{ml}$ was reported for Camellia sinensis, a recognized plant with several health-promoting benefits, including antioxidant and antimicrobial effects (ZIELINSKI et al., 2014). These reports support the high TPC content found in the present study for the most plant extracts studied. Also, DuDONNÉ and co-workers (2009) also reported that $C$. zeylanicum presented a high level of TPC (309.23 mg GAE/g) as found in the present study.

Highly significant correlations between TPC and antioxidant activity by DPPH $(-0.97$; $\mathrm{P}<0.0001)$ and ABTS $(0.96 ; \mathrm{P}<0.0001)$ were observed. Thus, these results suggest that phenolic compounds were the major group that strongly contributed to the antioxidant activities of the extracts. A major phenolic compound present in most of the plants is the gallic acid, a trihydroxy benzoic acid, which has a strong antioxidant activity due to the nucleophilic power of the three available hydroxyl groups (ZIELINSKI et al., 2014). These authors state that the antioxidant capacity of the species may differ due to dissimilarities in the soil composition, water stress, physiopathological conditions of the plant, and 
environmental conditions. Thus, the higher the level of antioxidant activity of the extract, the better the yield of the isolation of compounds of interest for large scale application.

Table 2.Total phenolic and flavonoid contents and antioxidant activity of the evaluated extracts

\begin{tabular}{|c|c|c|c|c|c|}
\hline Plant species & $\begin{array}{l}\text { Total phenolic } \\
\text { content } \\
\text { (mg GAE/g } \\
\text { extract) }\end{array}$ & $\begin{array}{l}\text { Total flavonoid } \\
\text { content } \\
\text { (mg CE/g } \\
\text { extract) }\end{array}$ & $\begin{array}{c}\mathrm{DPPH} \\
\mathrm{IC}_{50}\left(\mu \mathrm{g} \mathrm{ml}^{-1}\right)\end{array}$ & $\begin{array}{c}\text { ABTS } \\
(\mu \mathrm{mol} \mathrm{TEAC} / \mathrm{g})\end{array}$ & $\begin{array}{l}\% \mathrm{Fe}^{2+} \\
\text { chelation }\end{array}$ \\
\hline A. minus & $48.38 \pm 0.76^{\mathrm{h}}$ & $43.79 \pm 1.64^{\mathrm{f}}$ & $>25^{\mathrm{a}}$ & $369 \pm 8^{h}$ & $43.94 \pm 14.48^{\mathrm{d}}$ \\
\hline C. eugenioides & $199.46 \pm 4.66^{\mathrm{d}}$ & $63.07 \pm 2.34^{\mathrm{de}}$ & $6.07 \pm 0.09^{f}$ & $2445 \pm 71^{\mathrm{c}}$ & $71.82 \pm 3.56^{\mathrm{a}}$ \\
\hline C. zeylanicum & $261.13 \pm 3.74^{b}$ & $127.57 \pm 3.71^{\mathrm{a}}$ & $4.34 \pm 0.05^{\mathrm{h}}$ & $2600 \pm 64^{c}$ & $14.35 \pm 4.70^{\mathrm{f}}$ \\
\hline D. kaki & $78.60 \pm 4.52^{\mathrm{g}}$ & $47.60 \pm 0.82^{f}$ & $>25^{\mathrm{a}}$ & $619 \pm 35^{\mathrm{g}}$ & $46.71 \pm 0.93^{\mathrm{d}}$ \\
\hline E. uniflora & $220.07 \pm 13.11^{\mathrm{c}}$ & $38.67 \pm 1.76^{\mathrm{f}}$ & $5.26 \pm 0.14^{\mathrm{g}}$ & $2600 \pm 30^{\mathrm{c}}$ & $52.11 \pm 0.97^{\mathrm{cd}}$ \\
\hline P. rigida (leaves) & $150.45 \pm 3.29^{\mathrm{e}}$ & $63.43 \pm 3.73^{\mathrm{de}}$ & $7.05 \pm 0.07^{\mathrm{e}}$ & $1965 \pm 18^{d}$ & $38.23 \pm 3.42^{\mathrm{de}}$ \\
\hline P. rigida (bark) & $270.83 \pm 2.43^{b}$ & $73.52 \pm 5.17^{\mathrm{d}}$ & $4.56 \pm 0.03^{\mathrm{h}}$ & $4218 \pm 83^{\mathrm{a}}$ & $23.37 \pm 7.40^{\mathrm{ef}}$ \\
\hline P. americana & $39.80 \pm 1.05^{\mathrm{h}}$ & $67.83 \pm 1.09^{\mathrm{de}}$ & $>25^{\mathrm{a}}$ & $233 \pm 31^{\mathrm{h}}$ & $26.87 \pm 0.67^{\mathrm{ef}}$ \\
\hline P. edulis & $298.78 \pm 3.10^{\mathrm{a}}$ & $107.10 \pm 8.64^{b}$ & $3.73 \pm 0.12^{\mathrm{i}}$ & $3781 \pm 72^{b}$ & $69.55 \pm 2.40^{\mathrm{a}}$ \\
\hline P. cattleyanum & $204.01 \pm 3.33^{d}$ & $87.81 \pm 4.59^{c}$ & $5.76 \pm 0.19^{f}$ & $2107 \pm 31^{\mathrm{d}}$ & $62.12 \pm 3.37^{\mathrm{ab}}$ \\
\hline P. guajava & $125.75 \pm 4.32^{\mathrm{f}}$ & $60.45 \pm 2.77^{\mathrm{ef}}$ & $10.52 \pm 0.26^{\mathrm{c}}$ & $1248 \pm 38^{\mathrm{f}}$ & $70.16 \pm 0.66^{\mathrm{a}}$ \\
\hline S. terebinthifolius & $144.39 \pm 3.72^{\mathrm{e}}$ & $99.00 \pm 8.42^{\mathrm{bc}}$ & $10.93 \pm 0.11^{\mathrm{b}}$ & $1406 \pm 87^{\mathrm{f}}$ & $44.19 \pm 1.28^{\mathrm{d}}$ \\
\hline S. cumini & $199.99 \pm 7.75^{\mathrm{d}}$ & $47.71 \pm 0.94^{f}$ & $8.77 \pm 0.02^{\mathrm{d}}$ & $1717 \pm 139^{\mathrm{e}}$ & $54.26 \pm 2.96^{\mathrm{bc}}$ \\
\hline
\end{tabular}

Data are expressed as the mean of triplicate \pm SD. GAE: gallic acid equivalent; CE: catechin equivalent; $\mathrm{IC}_{50}: 50 \%$ inhibition capacity; TEAC: Trolox equivalent

${ }^{\mathrm{a}-\mathrm{i}}$ : Within a column, means \pm standard deviations with different superscript lowercase letters denote significant differences $(P<0.05)$ among the different plant species.

According to PÉREZ-JIMÉNEZ and co-workers (2008), the daily intake of phenolic compounds is on average $1 \mathrm{~g}$ per day. In this sense, the intake of $3.36 \mathrm{ml}$ per day of $P$. edulis extract (higher TPC in the present work) could provide all recommended quantity of phenolics. In the same way, the recommended intake of flavonoid compounds is about $70 \mathrm{mg}$ day $^{-1}$ in a Japanese cohort, one of the most advanced nations when considering well being and health (Hollman \& Katan, 1999). C. zeylanicum, P. edulis, S. terebinthifolius, and $P$. cattleyanum presented the highest concentrations of total flavonoid content $(\mathrm{P}<0.05)$. The catechol unit on the aromatic B-ring present in some flavonoid molecules stabilizes free radicals, and because of the presence of $o$-dihydroxy phenolic groups, it has the ability to chelate metals and proteins (ZIELINSKI et al., 2014). Thus, when considering the values reported in Japan, C. zeylanicum exceeds by almost twice the average daily consumption value of flavonoids in only 1 gram of extract. This makes this and other extracts presented here good choices for use in novel functional food formulations.

The chelating ability of the evaluated extracts with the ion $\mathrm{Fe}^{2+}$ is also presented in Table 2. Among the studied plant extracts, $C$. eugenioides, P. cattleyanum, P. guajava, and P. edulis presented the highest ability of complexing with $\mathrm{Fe}^{2+}(\mathrm{P}<0.05)$. Transition metal ions, such as $\mathrm{Fe}^{2+}, \mathrm{Cu}^{+}, \mathrm{Zn}^{2+}$, and $\mathrm{Mn}^{2+}$ may be involved in lipid oxidation as pro-oxidizer agents. Chelating agents, as they form complexes with metal ions, may prevent oxidative processes. It was reported that high $\mathrm{Fe}^{2+}$ chelating ability could be related with high flavonoid content, since these compounds contain several phenolic hydroxyl groups and a carbonyl group at the 

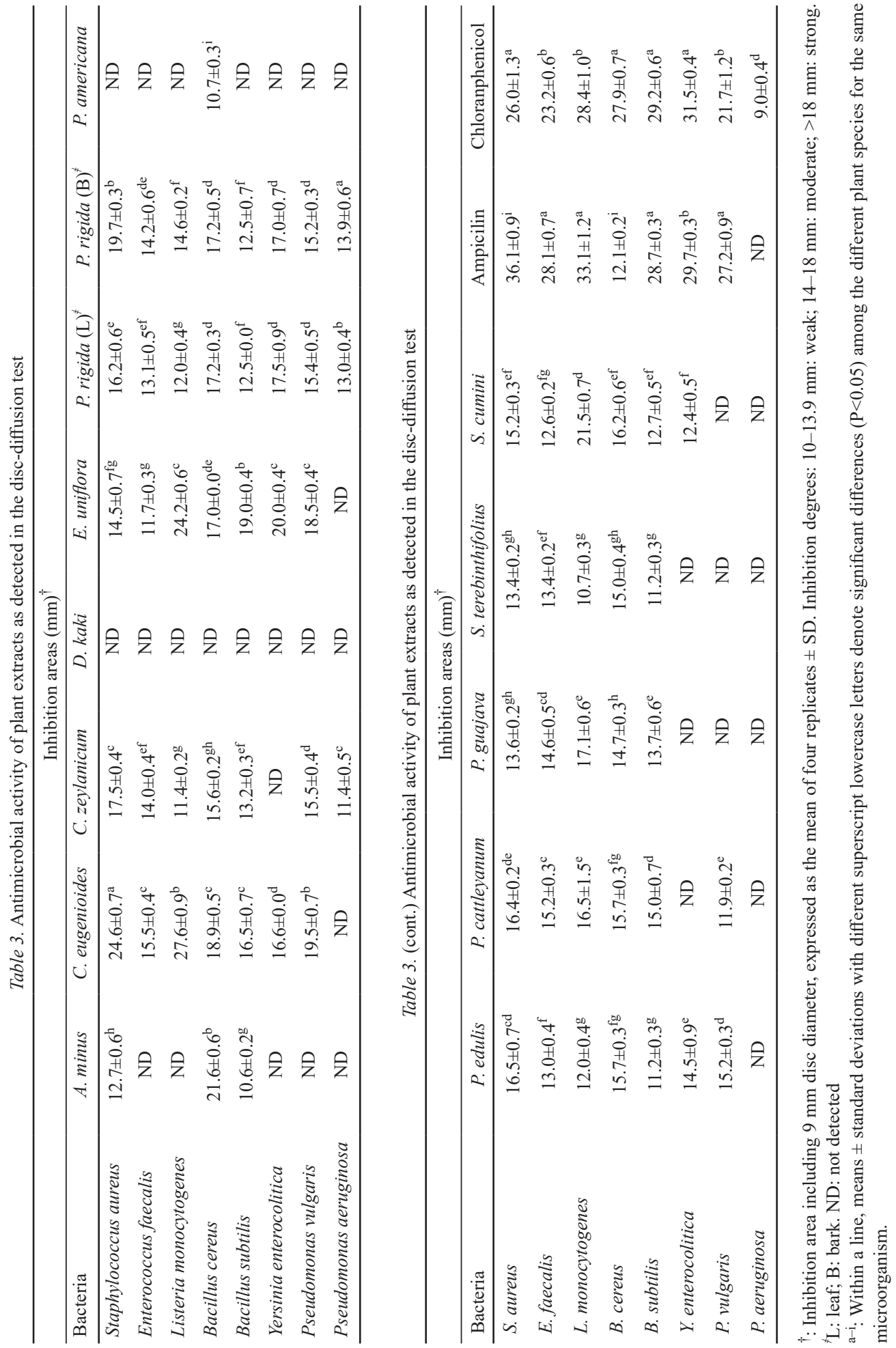
position 4 of the $\mathrm{C}$ ring, which could provide available sites for metal chelation (LEOPOLDINI et al., 2011). In the present study, P. edulis and P. cattleyanum extracts presented higher flavonoid levels and also higher ferrous ion chelating ability, which agrees with that observation.

C. eugenioides, C. zeylanicum, E. uniflora, P. rigida (bark and leaves), and P. edulis presented strong antimicrobial activity and spectrum against the tested bacterial species (Table 3). Gram-negative (G-) species E. coli, S. Typhimurium, and E. aerogenes, as well as the Gram-positive $\left(\mathrm{G}^{+}\right)$species, L. plantarum, were the most resistant among tested microorganisms, and were not inhibited by any of the extracts tested. In general, G+ species were more susceptible than $\mathrm{G}-$ ones, which is in agreement with several reports on natural antimicrobial agents. According to MALANOVIC and LOHNER (2016), G- bacteria have a lipopolysaccharide membrane in their cell wall that can interfere with some of these antibacterial substances blocking their activity. In a study on the mode of action of the carvacrol phenolic compound, UlTEE and co-workers (2002) stated that the hydroxyl group in its molecule is essential for its antibacterial action. Those authors proposed that this compound acts as a trans-membrane carrier for monovalent cations by exchanging its hydroxyl proton for another cation, such as $\mathrm{K}^{+}$, resulting in an additional decrease in the $\mathrm{pH}$ gradient and in the absence of a proton motive force, leading to the depletion of ATP and cell death.

As shown in Table 4, the results obtained in the antimicrobial activity assays (MIC and MBC) demonstrate that $P$. rigida bark extract and $C$. eugenioides extract presented the highest potential for application as natural antimicrobial agents. $C$. eugenioides extract was the most active against the tested $\mathrm{G}+$ species, all of which are important food-related pathogens. The extract derived from $P$. rigida bark presented the highest activity against the evaluated $\mathrm{G}-$ species, as shown by MIC and MBC results. The antimicrobial activity against the bacteria tested may be structure dependent and may be more influenced by specific phenolic compounds than by the total phenolic concentration in the extracts. In addition, among the factors that affect the leaching of phenolic compounds from the matrix, the polarity of the medium used can be included. Hydrophobic phenolic compounds have a better ability to alter the permeability of the cellular and mitochondrial membrane, making them more permeable with consequent losses of ions and molecules (MinATEL et al., 2017).

\section{Conclusions}

The obtained results, particularly those related to $P$. rigida and $C$. eugenioides extracts, provide new and relevant information on these Brazilian native species. $P$. rigida bark extract showed significant antioxidant activity, as detected by DPPH and ABTS radical scavenging tests, whereas $C$. eugenioides extract, in addition to scavenging free radicals, also presented high chelating capacity with $\mathrm{Fe}^{2+}$. Therefore, the combination of these two extracts seems also promising for the prevention of food oxidative damages. P. rigida bark extract and $C$. eugenioides extract also presented the highest potential of application as natural antimicrobial agents. $C$. eugenioides extract was the most active against the tested Gram-positive species, all of which are important food-related pathogens. The extract derived from P. rigida bark presented the highest activity against the evaluated Gram-negative species. Thus, the present study contributes to the knowledge on the biological activities of natural products and provides support for further researches and development of natural food additives.

*

The authors are grateful to FAPESC (08/2009, process FCTP 3302/091) for the financial support of this work. We also thank Dr. Arlei Coldebela for the help in statistical analysis. 


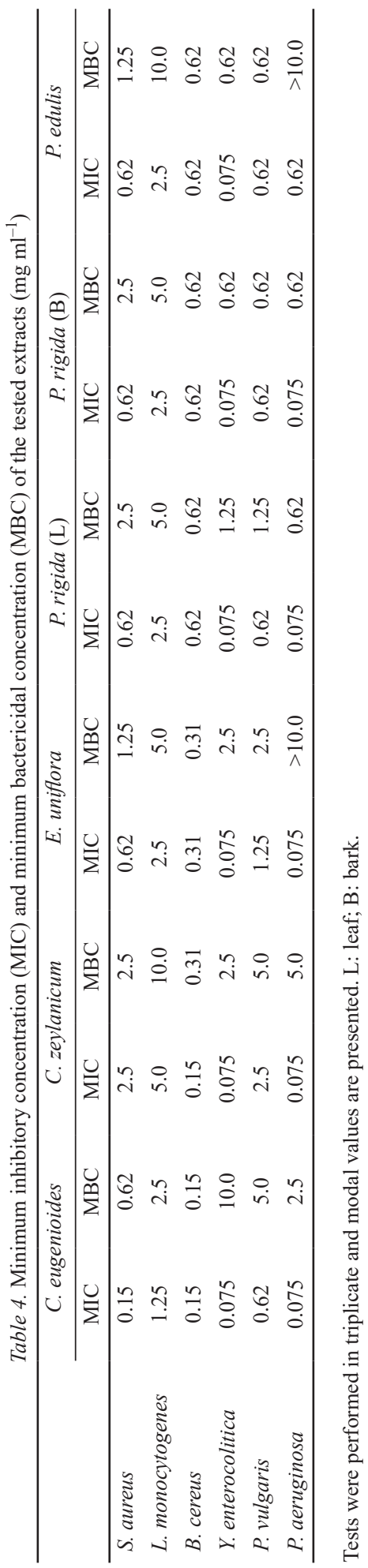




\section{References}

Brand-Williams, W., Cuvelier, M.E. \& Berset, C. (1995): Use of a free radical method to evaluate antioxidant activity. Food Sci. Tech., 28, 25-30.

CARTER, P. (1971): Spectrophotometric determination of serum iron at the submicrogram level with a new reagent - ferrozine. (1971): Anal. Biochem., 40, 450-458.

Celiktas, O.Y., Kocabas, E.E.H., Bedir, E., Sukan, F. V., OzeK, T. \& Baser, K.H.C. (2007): Antimicrobial activities of methanol extracts and essential oils of Rosmarinus officinalis, depending on location and seasonal variations. Food Chem., 100, 553-559.

ClSi (Clinical Laboratory Standards Institute) (2018a): Performance standards for antimicrobial disk susceptibility tests. Approved Standard, $13^{\text {th }}$ ed. CLSI document M02. Wayne, Pennsylvania, USA.

CLSI (CliniCAl Laboratory Standards Institute) (2018b): Methods for dilution antimicrobial susceptibility tests for bacteria that grow aerobically. Approved Standard, $11^{\text {th }}$ ed. CLSI document M07. Wayne, Pennsylvania, USA.

Dewanto, V., Wu, X., Adom, K.K. \& LiU, R.H. (2002): Thermal processing enhances the nutritional value of tomatoes by increasing total antioxidant activity. J. Agr. Food Chem., 50, 3010-3014.

Dudonné, S., Vitrac, X., Coutiere, P., Woillez, M. \& Mérillon, J. (2009): Comparative study of antioxidant properties and total phenolic content of 30 plant extracts of industrial interest using DPPH, ABTS, FRAP, SOD and ORAC assays. J. Agr. Food Chem., 57, 1768-1774.

Ebrahimabadi, A.H., Ebrahimabadi, E.H., Djafari-Bidgoli, Z., Kashi, F.J., Mazoochi, A. \& Batooli, H. (2010): Composition and antioxidant and antimicrobial activity of the essential oil and extracts of Stachys inflata Benth from Iran. Food Chem., 119, 452-458.

Hollman, P.C.H., Katan, M.B. (1999): Dietary flavonoids: Intake, health effects and bioavailability. Food Chem. Toxicol., 37, 937-942.

Leopoldini, M., Russo, N. \& TosCANo, M. (2011): The molecular basis of working mechanism of natural polyphenolic antioxidants. Food Chem., 125, 288-306.

Malanovic, N. \& Lohner, K. (2016): Antimicrobial peptides targeting Gram-positive bacteria. Pharmaceuticals (Basel), 9(3), 24-32.

Minatel, I.O., Borges, C.V., Ferreira, M.I., Gomez, H.A., Chen, C.-Y.O. \& Lima, G.P.P. (2017): Phenolic compounds: functional properties, impact of processing and bioavailability. -in: Soto-Hernandez, M., PaLmaTenango, M. \& Garcia-Mateos, M.R. (Eds) Phenolic compounds - Biological activity, Intechopen Ed. pp. $1-24$.

Oliveira, U., Soares, B.S., Paglia, A.P., Brescovit, A.D., Carvalho, C.J.B., .. \& S Santos, A.J. (2017): Biodiversity conservation gaps in the Brazilian protected areas. Nature Scientific Reports, 7, 9141.

Pérez-Jiménez, J., Arranz, S., Tabernero, M., Díaz-Rubio, M.E., Serrano, J. \& Goñi, I. (2008): Updated methodology to determine antioxidant capacity in plant foods, oils and beverages: Extraction, measurement and expression of results. Food Res. Int., 41, 27485.

Re, R., Pellegrini, N., Proteggente, A., Pannala, A., Yang, M. \& Rice-Evans, C. (1999): Antioxidant activity applying an improved ABTS radical cation decolorization assay. Free Radical Bio. Med., 26, 1231-1237.

Silveira, S.M., Luciano, F.B., Fronza, N., Cunha Jr., A., Scheuermann, G.N. \& Vieira, C.R.W. (2014): Chemical composition and antibacterial activity of Laurus nobilis essential oil towards foodborne pathogens and its application in fresh Tuscan sausage stored at $7{ }^{\circ} \mathrm{C}$. LWT-Food Sci. Technol., 59, 86-93

Singleton, V. L., Orthofer, R. \& Lamuela-Raventos, R.M. (1999): Analysis of total phenols and other oxidation substrates and antioxidants by means of Folin-Ciocalteu reagent. Methods Enzimol., 299, 152-178.

Ultee, A., Bennik, M.H.J. \& MoezelaAr, R. (2002): The phenolic hydroxyl group of carvacrol is essential for action against the food-borne pathogen Bacillus cereus. Appl. Environ. Microbiol., 68, 1561-1568.

ZapPI, D.C. \& BFG - The Brazil Flora Group (2015): Growing knowledge: an overview of seed plant diversity in Brazil. Rodriguésia, 66, 1085-1113.

Zielinski, A.A.F., Haminiuk, C.W.I., Alberti, A., Nogueira, A., Demiate, I.M. \& Granato, D. (2014): A comparative study of the phenolic compounds and the in vitro antioxidant activity of different Brazilian teas using multivariate statistical techniques. Food Res. Int., 60, 246-254. 